\title{
CLIMATE CHANGE ADAPTATION STRATEGIES BY LOCAL FARMERS IN KILOMBERO DISTRICT, TANZANIA \\ *BALAMA, C., ${ }^{1}$ AUGUSTINO, S., ${ }^{1}$ ERIKSEN, S., ${ }^{2}$ MAKONDA, F.S.B. ${ }^{1}$ and AMANZI, N. ${ }^{3}$ \\ http://dx.doi.org/10.4314/ejesm.v6i6.3S
}

Received 16th June 2013; accepted 28th October 2013

\begin{abstract}
This article examines current adaptation strategies developed by local farmers against climate change effects in Kilombero District. Research questions guided the study include; what are the past and current climatic stresses? What are local farmers' perception on climate change and response to the adverse climatic stresses? What are institutions and political structures influencing local farmer's adaptive capacity? The study was carried out in Mpofu, Njage and Miwangani villages. Data were collected through participatory rural appraisal, key informant interviews, household questionnaire interviews and focus group discussions. Findings show that there is prevalence of climate stresses including; prolonged dry spells, unpredictable floods, pests and diseases. Due to these stresses farmers have developed local adaptation strategies which are farming and non-farming. Farming strategies were crop diversification for food and cash and shift of cropping calendar. Non-farming strategies include the use of forest products, livestock rearing, fishing, petty trade, casual labours and remittances. Inferential statistics show that family size, number of years the respondent lived in the village, trend of rainfall and temperature are the factors influencing adaptation strategies positively. The study recommends local adaptation strategies to be streamlined to relevant policies in order to enhance local farmers' adaptive capacity and become helpful in facing both present and future climate change effects.
\end{abstract}

Keywords: Climate Change, Farmers, Stresses, Perceptions, Adaptation, Tanzania

\section{Introduction}

Climate change is among the problems that hinder sustainable livelihoods and economic development, particularly for developing countries like Tanzania (Shemsanga et al., 2010). Tanzania is seriously affected since it depends primarily on rain-fed agriculture, with only $2 \%$ of arable land having irrigation facilities (Shemsanga et al., 2010). Local farmers with low adaptive capacity are thought to be more vulnerable to adverse effects of climate change, which contributes to the loss of their natural resources (Eriksen et al., 2005; Paavola, 2008). Due to current effects of climate change, local farmers in Kilombero District including their livelihood assets are vulnerable to unpredictable

${ }^{1}$ Department of Wood Utilization, Sokoine University of Agriculture, P.O. Box 3034, Chuo Kikuu, Morogoro, Tanzania.

${ }^{2}$ Noragric, Department of Environment and Development

Studies, Norwegian University of Life Sciences, P.O. Box 5003,

N-1432 As, Norway.

${ }^{3}$ Tanzania Forestry Research Institute, P.O. Box 1854,

Morogoro, Tanzania.

*Corresponding author: balamapc@yahoo.co.uk floods, prolonged dry spells, pests and diseases, thus calling for adaptation strategies to be undertaken (Chamwali, 2000; Abdulla, 2000).

Adaptation to climate change indicates processes taken to enable communities to have ability to survive with the state of climate shift. IPCC (2007a) defined adaptive capacity as the ability of the systems to adjust to climate change and has three components: awareness, ability and action. Adaptive capacity is among the determinants of vulnerability of a system, others being exposure and sensitivity (Metzger et al., 2006). It is possible that vulnerable farmers organise livelihood resources and develop adaptation strategies, with the existing institutions being taken into the context (Naess et al., 2005). It is against this background, a study to analyse local adaptation strategies developed by local farmers, against climate change effects in 
Kilombero District was carried out. The following research questions guided the study: what are the climatic stresses and its effects on livelihood assets? What are local farmers' perception on climate change and response to the adverse climatic stresses? What are institutions and political structures influencing local farmers' adaptive capacity?

\section{Methodology}

\section{Description of Study Area}

The study was conducted in three villages of Kilombero District. The district is located between $08^{\circ} 00^{\prime}-16^{\circ}$ South and $36^{\circ} 04^{\prime}-36^{\circ} 41^{\prime}$ East, with elevation ranging from 262 to of 550 $\mathrm{m}$ a.s.1 and covering 14,246 $\mathrm{km}^{2}$. The study villages were Mpofu, Njage and Miwangani (Fig. 1). Climate is marked by a rainy season from November to May and a dry season from June to October with annual rainfall and temperature ranging between 1200 and $1800 \mathrm{~mm}$, and $26^{\circ} \mathrm{C}$ to $32^{\circ} \mathrm{C}$, respectively (Hetzel et al., 2008). Access to the study villages is through an earth road from Ifakara Town to Mlimba; as well as the railway line (Tanzania-Zambia Authority (TAZARA)) that extends from Dar es Salaam to Kapiri Mposhi in Zambia (Hetzel et al., 2008). Ethnic groups are seemingly diverse, but still share similar livelihoods and socio-cultural norms. Hehe ethnic group dominates in both Mpofu and Njage villages, whereas Ndamba, Pogolo and Hehe in Miwangani. The main economic activities include agriculture and livestock rearing (Table 1).

\section{Research Designs and Approach}

The study adopted a cross-sectional research design whereby data were collected only once.

\section{Sampling Procedure}

Purposive sampling was employed to select study villages. Two villages, Mpofu and Njage which are adjacent to Kilombero Nature Reserve (KNR) were selected and Miwangani Village, which is $25 \mathrm{~km}$ away from the forest, was selected for comparison purpose. All villages fall under similar climatic conditions.
Multi-stage sampling procedure was used to select households. Households were first stratified into "low income' "middle income" and "high income" wealth categories based on villagers' criteria in order to control livelihoods variability. This was done during wealth ranking exercises that were conducted in each village. Criteria used include type of house, farm size, means of transport, annual income, education, health care, food security and source of energy. Thereafter, in each group, male and femaleheaded households were identified. Random sampling technique was used to select 60 households per village for questionnaire survey, whereby 30 households represent the low income group and 15 for middle and high income groups each, from the village register.

\section{Data Collection Methods}

The study involved both qualitative and quantitative data collection methods. Qualitative data were collected through PRA, Focus Group Discussions (FGDs) and key informant interviews. Household questionnaire survey was used to collect both qualitative and quantitative data. Climatic data for the past 30 years (19802010) were collected from the Tanzania Metrological Agency (TMA). Data collected climatic stresses and its effects on livelihood assets, local farmers' perception on climate change and response to the adverse climatic stresses, institutions and governance structures influencing local farmers' adaptive capacity.

\section{Data Analysis}

Content analysis was employed in analysing qualitative data collected through PRA, key informant interviews and FGDs. Descriptive statistics including frequency, percentages, means and inferential statistics were carried out to quantify data from household questionnaire and climatic data. For testing research hypothesis multiple regressions was used. 


\section{Results and Discussion Characteristics of Respondents}

Age of respondents varied as from 20 to 80 years. Age group of 31-40 years was dominant with 35\% in Mpofu, $28.3 \%$ in Njage and 30\% in Miwangani (Table 2).

Majority of the respondents $88.3 \%$ in Mpofu, $70 \%$ in Njage and 65\% in Miwangani had attained primary education (Table 2). Land size varied across different classes, whereby most of the respondents in Mpofu (55\%), Njage (75\%) and Miwangani $(51.7 \%)$ had land sizes that are within $0.28-1.21$ ha. The reported land size per household was claimed to be relatively small. Land scarcity attributed to their current locality. All surveyed villages are situated between two reserved lands: Kilombero Nature Reserve and Kilombero Ramsar Site. The study further revealed that most of the respondents were non natives from outside the region as reported by $58.3 \%$ and $61.7 \%$ of respondents in Mpofu and Njage, respectively.

Climate stresses and perception on climate change in the study sites

Climate stresses in the study areas

The study area experiences the following climate stresses: dry spells, floods, extreme temperatures, water shortage, heat stress and storm surges. Mentioned stresses were first experienced in 1970s in all study sites. Recorded climate stresses are in line with stresses outlined in the IPCC (2007a). Respondents claimed to experience dry spells that have reduced crop yields since causing moisture stress. Majority of respondents in Miwangani (100.0\%) and Njage $(87.5 \%)$ reported that crops have been drying due to moisture stresses. Moisture stresses was related to outbreak of Rice Mottle Yellow Virus (RYMV), locally known as kimyanga. Allarangaye et al. (2006) reported that RYMV is the most important viral disease for rice in Africa which reduces its productivity. Moisture stresses also a fundamental cause of susceptibility of the crops to other stresses like pests. Pests observed include in surveyed area include grasshopper species Zonocerus variegates L. (panzi-kunuka) and army-worms (viwavi-jeshi). The grasshoppers and army-worms were much reported in Mpofu (41.4\%) and Njage (37.9\%) and less in Miwangani village (Table 3).

Increased temperatures and prolonged dry spells accelerate drying up of water sources, thus reducing water flow in rivers. Water shortage has resulted to prevalence of waterborne diseases like cholera, typhoid, dysentery and amoebic diseases. This could be due to insufficient of safe water for domestic use. Most of the households depend on rivers, shallow wells, water hand pumps (mdundiko) and rain water for domestic use. Cholera occurred during periods of floods due to increased rate of germs/vectors that cause the disease. High rate spread of waterborne diseases may be boosted by extreme climate conditions that could be favourable for survival of the vectors (Augustino et al., 2012). Increase in temperature is associated with other human diseases like malaria, skin rushes, dengue, tick borne and diarrhoeal diseases as was also reported by Hetzel et al. (2008) and Augustino et al. (2012).

\section{Climate change perception by local farmers}

Local farmers perceive presence of climate change through frequent changes and variability in rainfall and temperature. Table 4 shows perceptions of the local farmers based on rainfall and temperature trends. Most of the respondents in Mpofu (75.5\%), Njage (81.0\%), and Miwangani (89.7\%) agreed that, there is delay in onset of the first rainy season than before. The first rain season cessation was mentioned to be earlier. These two perceptions were consistent with the perceived shorter rainy season in all study sites. The study further revealed most stressful year. High proportion of respondents in Mpofu (56.1\%) mentioned 2011 as was the most stressful year, while in Njage (57.9\%) and Miwangani (64.4\%) reported the last 10 years from 1996 to 2005 as the most stressful years. ElNino occurred in 1998/1999 which had prolonged dry spells as well as floods, was the most cited climate stress in the entire period in all surveyed villages. 


\section{Rainfall trend in the study area}

Figure 2 shows monthly trend of rainfall during rainy and dry seasons from year 1980 to 2010. The rainfall trend between decades was not statistically significant different at $\mathrm{p}>0.05$. However, there are variations on the onset and cessation of rainy and dry season. The last decade (2000-2010) shows a trend of shift on cessation of the long rains as compared to the previous two decades. This indicates that, the dry season comes early thus affecting crop yields, as the maturity period is reduced. As the rainy season decreases for the last decade, this signifies the increase of dry season which has negative effect on the crop production. Similarly, decline in rainfall has also reduced availability of other livelihood resources apart from agricultural crops. For example, mushrooms and some wild fruits which are dietary source of protein and vitamins respectively were reported to decline. The findings are similar to those reported by Devisscher (2010) and Nkem et al. (2010). In Miwangani, it was reported that reduced precipitation favoured growth of plants that produce weavings; Phoenix reclinata Jacq. (ukindu), and Hyphaene compressa $\mathrm{H}$. Wendel. (malala) even though such weather condition does not favour rice production.

\section{Vulnerable livelihood assets}

Basing on the observed climate stresses in the study area, the following livelihood assets were vulnerable; agricultural lands, crops, houses, roads, rivers, ponds and forests. Majority of respondents reported that agricultural lands were most vulnerable to floods (Table 5). Frequent flooding also causes sheet erosion which removes top soils leaving unfertile soils. This might increase crop production costs as farmers are forced to use inorganic fertilizers for high productivity. Thus, increase vulnerability to some social groups whom do not have ability to buy inorganic fertilizers. Other livelihood assets vulnerable to floods were roads, houses and forests. It was reported that floods of 1998 eroded part of the road that connect study villages to Ifakara Town. This affected local farmers to access social services such as hospitals, markets, railway station, police station, and administrative services.

The study further revealed vulnerability to livelihood assets such as farms, rivers, ponds and forest resources due to dry spells. Dry spells were reported to affect crop productivity as planted crops dried before matured. The most affected crops were rice, maize and banana. Similarly, rivers and ponds were vulnerable to dry spells, as water level reduced and some become seasonal. Different social groups like children, women, elder people and widows used to benefit from the rivers and ponds. Dry spells also pose vulnerability to forests and grasslands due to wildfires as was reported in Njage. According to the IPCC (2007b) 'extended warm periods and increased droughts increase water stress in forests and grasslands thus increasing frequency and intensity of wildfires'.

\section{Farmers' adaptation strategies to the adverse climatic stresses}

Following the realised adverse climate stresses, local farmers have acted in numerous ways. The response has been farming and nonfarming. Farming strategies include crop diversification, changing cropping calendar, and adopting modern farming techniques. Crop diversification involves growing different varieties of food and cash crops, some of which are resistant to dry spells and some pests and diseases. Similar studies elsewhere indicate how crop diversification has been important as a way of adapting to climate change effects (Ellis, 2000). As part of crop diversification, nontraditional crops grown include; cassava (Manihot esculenta Crantz), sesame (Sesamum indicum L.), cocoa (Theobroma cacao L.), sweet potatoes (Ipomoea batatas L.) and pigeon peas (Cajanus cajan L.). Traditional crops are rice (Oryza sativa L.), banana (Musa spp.) and maize (Zea mays L.) (Table 6). Cash crops like sesame and cocoa constitute of recent activities. In Mpofu, sesame has been grown since 2000, while in Njage and Miwangani started in 2007. 
Farmers are now shifting crop growing calendar through early cultivation as currently rains are neither reliable nor predictable. Currently, farmers are using the first rains in November for crop planting, as in the past were left for weeds to germinate. With regard to adoption of modern farming, the study revealed availability of irrigation canal in Njage used for rice production that was constructed in 2006. Use of pesticides, herbicides and line planting instead of spreading seeds is also being adopted. Nonfarming adaptation strategies included livestock rearing, fishing, petty business, casual labour and remittances. Generally this is a form of livelihood diversification, which draws attention to variety of dissimilar income sources (Kamanga et al., 2009).

Local farmers' adaptation strategies against climate stresses differed from villages that are near the forest resources compared to those located at distant. About $60.3 \%$ and $(44.4 \%)$ of the respondents in Njage and Mpofu, respectively used mushrooms as their immediate vegetable especially when there are no other alternatives. None of the respondents from Miwangani declared use of the mushrooms; this is because such products are not available. About $35.9 \%$ of the respondents in Miwangani use weavings known as malala to make mats (Table 7). Use of forest products as adaptation strategy during extreme weather conditions is well emphasized in the National Adaptation Programme of Action (NAPA) document (URT, 2007).

Table 8 presents results of multiple regression analysis on variables that influence adaptation strategies by local farmers. The results show that, family size $\left(\mathrm{X}_{4}\right)$, number of years the respondent lived in the village $\left(\mathrm{X}_{5}\right)$, trend of rainfall $\left(\mathrm{X}_{12}\right)$ and temperature $\left(\mathrm{X}_{14}\right)$ are the factors influencing adaptation strategies positively at $5 \%$, thus explaining about $40 \%$ of the variation in the local farmers' adaptation strategies. Age $\left(\mathrm{X}_{2}\right)$ of the respondents influenced adaptation strategies negatively however was significant at 5\%. Other factors [except occupation $\left(\mathrm{X}_{7}\right)$ and number of climate stresses
$\left.\left(\mathrm{X}_{11}\right)\right]$ influenced adaptation strategies positively but not significantly at $5 \%$. The findings of this study are similar to other studies done in Africa (Ayanwuyi et al., 2010; Mbwambo et al., 2013).

\section{Institutions and organisations influencing} climate stresses adaptation by farmers

The study revealed formal and informal institutions and organisations that influenced local farmers' adaptation against climate extremes. Formal and informal institutions recorded include churches, Village Government, Village Community Banks (VICOBA), Savings and Credit Cooperative Organizations (SACCOs), custom and traditions. Churches provided support to people during extreme events like floods, dry spells, outbreak of pests and diseases. The Village Government was active in securing camping areas and facilities, organising well distribution of relief food and shelter. Micro financial institutions (MFIs) provide financial support through loans. Villages with MFIs, have better adaptive capacities than those without these facilities (Berman et al., 2012). Custom and traditions were used in the past for worship especially during stressful years.

Organisations recorded include Plan International and Kilombero Plantations Limited (KPL). Plan International operates in Miwangani and Mpofu and other villages in Mbingu and Idete wards. Plan International deals mostly with development activities like construction of schools, roads, water wells and supporting orphans. KPL operates in Njage by building capacity to farmers how to cultivate rice using modern techniques including planting rice using seedlings, and use of improved seed varieties.

\section{Political structures and frameworks affecting climate change adaptation process}

Change in policies governing forest resources and agriculture have affected access to the livelihoods to households. Change in forest regime from forest reserve to nature reserve was effected in 2007, aiming in increasing biodiversity conservation measures. Nature reserve is a high level of conservation which limits access to products by farmers. This is 
evident in farmers from Mpofu and Njage villages. Limiting access to forest products have affected some social groups particularly women, children and elder people. Land is also a problem especially in Miwangani and Njage villages where part of the agricultural land is within the Kilombero Ramsar Site. The Kilombero Ramsar Site is a fertile wetland along the Kilombero River floodplain (Bakengesa et al., 2011), whereby people in Njage and Miwangani villages used for agriculture. The government of Tanzania endorsed the Ramsar Convention in 2000 on the wise use of wetlands making it free from anthropogenic activities (Bakengesa et al., 2011). Farmers and pastoralists who used to be in the wetland have been evicted since September 2013. Such situation increases vulnerability to farmers particularly women and elders who do not have capacity to buy land in other places. The findings are similar to those by Eriksen and Lind (2009) when studying influence of political processes on adaptation in Kenya.

\section{Conclusion}

The study has recorded prevalence of climate stresses including; prolonged dry spells, unpredictable floods, heavy rains, pests and diseases. Rainfall data have shown a trend of slight decline from the past decades as compared to the present. The trend of decline in rainfall (1980-2010) was not statistically significant different at $\mathrm{p}>0.05$ level. However, there are variation on the onset and cessation of rain and dry season. Due to experienced adverse climatic conditions and other stressors, local farmers are responding through different adaptation strategies which include farming and non-farming activities. Farming strategy involves growing of both diversified traditional and non-traditional food and cash crops. Non-farming adaptation strategies include use of forest products, livestock rearing, fishing, petty business and casual labour. Forest products from adjacent forests include; mushrooms, grasses, weavings, ropes, fruits and medicines. Use of weavings and grasses was much practised in Miwangani, as they are limited to other types of forest products. Institutions and organisation that enhance adaptive capacity to local farmers were recorded. Change in policies that govern forest resources and agricultural land, limits access to livelihoods by farmers; thus reducing adaptive capacity to marginalised people especially women, children and elder people.

\section{Recommendation}

The study draws the following recommendations; There is need to increase awareness to local farmers on livelihood diversification;

Capacity building on commercialisation, value addition and market improvement for forest products is pertinent;

It is important to integrate climate change local adaptation strategies into relevant policies so that local farmers' adaptive capacity is enhanced; and Available institutions and organisations should well define their objectives to local farmers and work together in order that there is no duplication of efforts.

\section{Acknowledgement}

Authors would like to thank the Climate Change Impacts and Mitigation (CCIAM) Programme Tanzania through NORAD for financial support. Authors recognise the high level of cooperation and valuable contribution received from the communities. Authors send sincerely thanks to Mr. Castor Chelela for facilitating communication. 


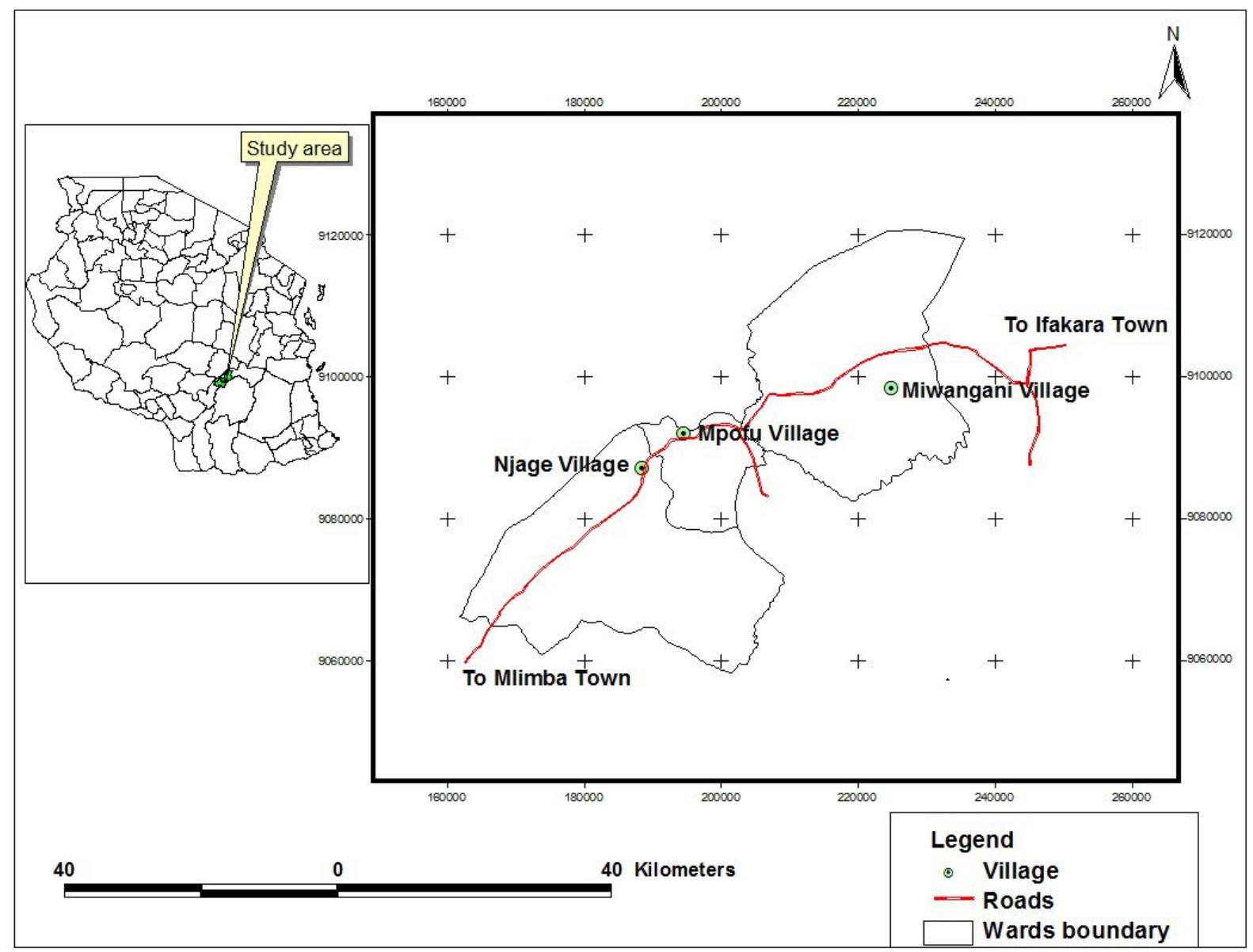

Figure 1 A map showing location of study villages in Kilombero District, Tanzania 
Climate Change Adaptation Strategies by Local Farmers in Kilombero.................BALAMA et al.

Table 1 Some physical and demographic characteristics of Mpofu, Njage and Miwangani villages in Kilombero District

\begin{tabular}{|c|c|c|c|}
\hline Characteristics & Mpofu & Njage & Miwangani \\
\hline Mean altitude (m) & 295 & 312 & 272 \\
\hline $\begin{array}{l}\text { Population of } \\
\text { people }\end{array}$ & $\begin{array}{c}3,123 \text { (males } 1,216 \text {, females } \\
1,907)\end{array}$ & $\begin{array}{c}3,402 \text { (males } 1,720 \text {, females } \\
1,678)\end{array}$ & $\begin{array}{c}2,545 \text { (males } 1,241, \text { females } \\
1,304)\end{array}$ \\
\hline $\begin{array}{l}\text { Number } \\
\text { households }\end{array}$ & 714 & 868 & 581 \\
\hline $\begin{array}{l}\text { Average household } \\
\text { size }\end{array}$ & 4.72 & 4.78 & 4.93 \\
\hline $\begin{array}{l}\text { Average land size } \\
\text { (ha)/household }\end{array}$ & 1.32 & 1.30 & 1.77 \\
\hline Crops grown & $\begin{array}{l}\text { Main (banana, maize, rice), } \\
\text { others (sesame, cocoa, cassava) }\end{array}$ & $\begin{array}{l}\text { Main (rice, banana, maize), } \\
\text { others (sesame, cassava). }\end{array}$ & $\begin{array}{l}\text { Main (rice, maize, banana) } \\
\text { others (sesame, cassava). }\end{array}$ \\
\hline Livestock & $\begin{array}{l}\text { Main (local chicken, cattle), } \\
\text { others (ducks, dogs). }\end{array}$ & $\begin{array}{l}\text { Main (local chicken, cattle), } \\
\text { others (ducks, pigs). }\end{array}$ & $\begin{array}{l}\text { Main (local chicken, cattle), } \\
\text { others (ducks, pigs). }\end{array}$ \\
\hline Fruits & $\begin{array}{l}\text { Main (mangoes), others } \\
\text { (avocado, pawpaw). }\end{array}$ & $\begin{array}{l}\text { Main (mangoes), others } \\
\text { (avocado, pawpaw). }\end{array}$ & $\begin{array}{l}\text { Main (mangoes), others } \\
\text { (avocado, pawpaw) }\end{array}$ \\
\hline Trees & Senna, teak, neam tree & Senna, teak, neam tree. & Senna, teak, neam tree. \\
\hline Ethnic groups & $\begin{array}{l}\text { Main (hehe, nyakyusa, bena, } \\
\text { ndali), others (sukuma, makua, } \\
\text { kerewe, gita, ndamba, pogolo, } \\
\text { nyamwezi, haya, safa, and } \\
\text { kinga,). }\end{array}$ & $\begin{array}{l}\text { Main (hehe, bena, nyakyusa, } \\
\text { ndamba), others (sukuma, } \\
\text { pogolo, kerewe, gita, nyamwezi, } \\
\text { chaga and matumbi). }\end{array}$ & $\begin{array}{l}\text { Main (ndamba, pogolo, hehe, } \\
\text { and sukuma), others (nyakyusa, } \\
\text { ndali, luguru, bena, nyika, } \\
\text { kinga, and matumbi). }\end{array}$ \\
\hline
\end{tabular}


Ethiopian Journal of Environmental Studies and Management Vol. 6 Supplement 2013

Table 2 Characteristics of respondents in the study villages in Kilombero District

\begin{tabular}{|c|c|c|c|}
\hline \multirow[t]{2}{*}{ Variable } & \multicolumn{3}{|c|}{ Frequency $(\%)$} \\
\hline & Mpofu & Njage & Miwangani \\
\hline $\begin{array}{l}\text { Age group } \\
20-30\end{array}$ & 20.0 & 15.0 & 10.0 \\
\hline $31-40$ & 35.0 & 28.3 & 30.0 \\
\hline $41-50$ & 25.0 & 26.7 & 21.7 \\
\hline $51-60$ & 5.0 & 10.0 & 18.3 \\
\hline 61 and above & 15.0 & 20.0 & 20.0 \\
\hline \multicolumn{4}{|l|}{ Sex } \\
\hline Male & 60.0 & 46.7 & 43.3 \\
\hline Female & 40.0 & 53.3 & 56.7 \\
\hline \multicolumn{4}{|l|}{ Marital status } \\
\hline Single & 6.7 & 1.7 & 3.3 \\
\hline Married & 88.3 & 88.3 & 81.7 \\
\hline Widow & 5.0 & 8.3 & 13.3 \\
\hline Separated & $\mathrm{nr}$ & 1.7 & 1.7 \\
\hline \multicolumn{4}{|l|}{ Level of education } \\
\hline Non- formal & 10.0 & 30.0 & 31.6 \\
\hline Primary & 88.3 & 70.0 & 65.0 \\
\hline Secondary & 1.7 & $\mathrm{nr}$ & 1.7 \\
\hline Post-secondary & $\mathrm{nr}$ & $\mathrm{nr}$ & 1.7 \\
\hline \multicolumn{4}{|l|}{ Occupation } \\
\hline Peasant & 98.3 & 100.0 & 100.0 \\
\hline Employed & 1.7 & 8.3 & $\mathrm{nr}$ \\
\hline Business & 5.1 & 13.3 & 1.7 \\
\hline Livestock keeping & 11.9 & 1.7 & $\mathrm{nr}$ \\
\hline \multicolumn{4}{|l|}{ Place of origin } \\
\hline In the village & 31.7 & 26.7 & 30.5 \\
\hline Outside the village but within the district & 10.0 & 11.7 & 45.8 \\
\hline Outside the region & 58.3 & 61.7 & 23.7 \\
\hline
\end{tabular}

Note: $\mathrm{nr}=$ no response

Table 3 Climate stresses in the study area

\begin{tabular}{lccc}
\hline Climate stresses & \multicolumn{3}{c}{ Frequency $(\%)$} \\
\cline { 2 - 4 } & Mpofu & Njage & Miwangani \\
\hline Dry spells & 96.6 & 96.6 & 95.0 \\
Floods & 50.0 & 19.0 & 13.3 \\
Grasshoppers and army-worms & 41.4 & 37.9 & 2.1 \\
Malaria & 24.1 & 41.4 & 30.0 \\
Water borne diseases & 12.1 & 22.4 & 23.3 \\
Rice Mottle Yellow Virus disease & 3.4 & 10.3 & 58.3 \\
Storms & 5.2 & 1.7 & 1.7 \\
\hline
\end{tabular}


Table 4 Local farmers' perception on climate change in the study area

\begin{tabular}{lccc}
\hline Variable & \multicolumn{3}{c}{ Frequency (\%) } \\
\cline { 2 - 4 } & Mpofu & Njage & Miwangani \\
\hline Rainfall trend & & & 89.7 \\
Delay in onset of rain season & 75.5 & 32.8 & 36.2 \\
Early cessation of rain season & 11.3 & 5.2 & $\mathrm{nr}$ \\
Lack of rains during dry seasons & 17.0 & 27.6 & 19.0 \\
Shortage of rains & $\mathrm{nr}$ & $\mathrm{nr}$ & 5.2 \\
Change of raining season & & & 100.0 \\
Increased temperature & 50.0 & 87.5 & 31.2 \\
Drying of crops & 20.0 & 8.3 & 12.2 \\
Increased human diseases & 17.0 & 9.3 & 25.0 \\
Drying of rivers and ponds & $\mathrm{nr}$ & $\mathrm{nr}$ & 18.8 \\
Increasing of pests & $\mathrm{nr}$ & 8.3 & 6.2 \\
Increasing of livestock diseases & 20.0 & $\mathrm{nr}$ & 49.2 \\
Delays of rainfall & & & 11.9 \\
Stressful year & 21.1 & 35.1 & 18.6 \\
2012 & 56.1 & 26.3 & 64.4 \\
2011 & 14.0 & 12.3 & 5.1 \\
2010-2006 & 38.6 & 57.9 & 8.8 \\
\hline
\end{tabular}

Note: $\mathrm{nr}=$ no response

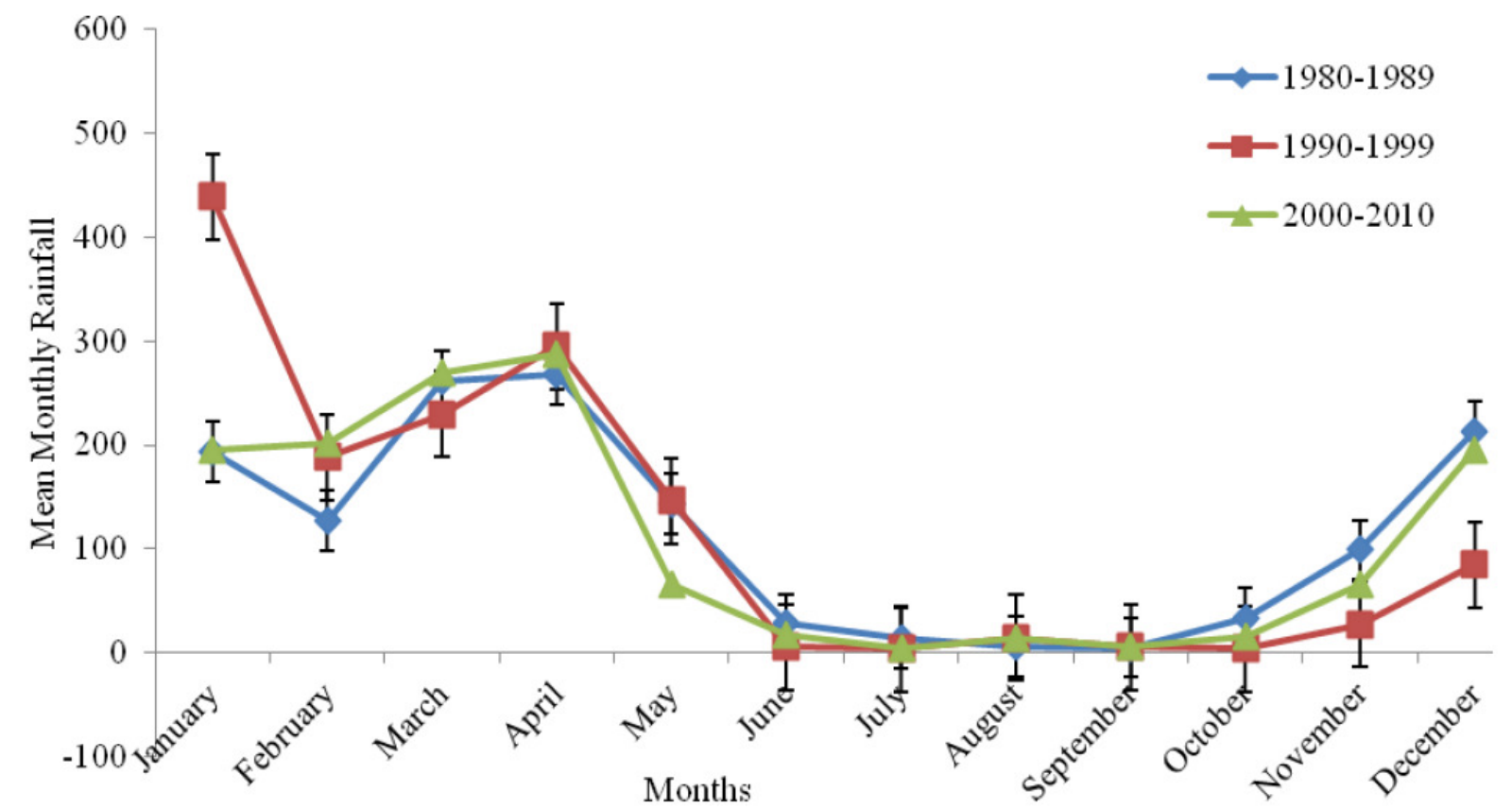

Figure 2 Mean monthly rainfall for three decades (1980-2010) in Kilombero District, Tanzania. 
Table 5 Livelihood assets affected by climate stresses in the study area

\begin{tabular}{lccc}
\hline Livelihood affected & \multicolumn{2}{c}{ Frequency (\%) } \\
\cline { 2 - 4 } & Mpofu & Njage & Miwangani \\
\hline Agricultural fields and crops & 100.0 & 100.0 & 97.4 \\
Houses & 26.8 & 4.0 & $\mathrm{nr}$ \\
Livestock & 31.7 & 8.0 & 17.9 \\
Rivers and ponds & 14.4 & 10.7 & 7.4 \\
Forest products & 0.8 & 5.5 & $\mathrm{nr}$ \\
Roads & 4.9 & $\mathrm{nr}$ & $\mathrm{nr}$ \\
\hline
\end{tabular}

Note: $\mathrm{nr}=$ no response

Table 6 Main crops (traditional and non-traditional) grown in the study area

\begin{tabular}{lccc}
\hline Crops grown & \multicolumn{3}{c}{ Frequency (\%) } \\
\cline { 2 - 4 } & Mpofu & Njage & Miwangani \\
\hline Traditional crops & & & 100.0 \\
Paddy & 71.2 & 98.3 & 86.7 \\
Maize & 94.9 & 86.7 & 51.7 \\
Banana & 62.7 & 43.3 & $\mathrm{nr}$ \\
Coconut & 1.7 & 1.7 & 3.3 \\
Non-traditional crops & & & 11.7 \\
Sesame & 52.5 & 6.7 & 21.7 \\
Cassava & 6.8 & 48.3 & $\mathrm{nr}$ \\
Sweet potatoes & 6.8 & 21.7 & 1.7 \\
Cocoa & 6.8 & 1.7 & 1.7 \\
Groundnuts & 3.4 & 16.7 & $\mathrm{n}$ \\
Pigeon peas & 1.7 & $\mathrm{nr}$ & 18.3 \\
Cow peas & $\mathrm{nr}$ & & 13.3 \\
\hline
\end{tabular}

Note: $\mathrm{nr}=$ no response

Table 7 NTFPs used against climate stresses effects

\begin{tabular}{lccc}
\hline NTFPs & \multicolumn{3}{c}{ Frequency $(\%)$} \\
\cline { 2 - 4 } & Mpofu & Njage & Miwangani \\
\hline Mushrooms & 44.4 & 60.3 & $\mathrm{nr}$ \\
Construction materials (poles, withes, thatching grass, ropes) & 20.0 & 5.2 & 5.1 \\
Firewood & 11.1 & 13.8 & 4.0 \\
Edible fruits & 2.2 & 1.7 & $\mathrm{nr}$ \\
Tubers & $\mathrm{nr}$ & 12.1 & $\mathrm{nr}$ \\
Local medicines & $\mathrm{nr}$ & 1.7 & $\mathrm{nr}$ \\
Weavings (malala) & 2.2 & $\mathrm{nr}$ & 35.9 \\
Weavings (ukindu) & $\mathrm{nr}$ & $\mathrm{nr}$ & 17.9 \\
Fodder & $\mathrm{nr}$ & 1.7 & $\mathrm{nr}$ \\
\hline
\end{tabular}

Note: $\mathrm{nr}=$ no response 
Table 8 Regression analysis on variables influencing adaptation strategies

\begin{tabular}{|c|c|c|c|c|}
\hline \multirow[t]{2}{*}{ Independent variables } & \multirow[t]{2}{*}{ Estimate (B) } & \multirow[t]{2}{*}{ t-value } & \multicolumn{2}{|c|}{$95 \%$ Confidence Interval for B } \\
\hline & & & Lower Bound & Upper Bound \\
\hline Constant & $-0.623(0.639)$ & -0.871 & -2.036 & 0.790 \\
\hline $\operatorname{Sex}\left(\mathrm{X}_{1}\right)$ & $0.069(0.121)$ & 0.880 & -0.129 & 0.337 \\
\hline Age $\left(X_{2}\right)$ & $-0.369(0.006)$ & $-3.687^{*}$ & -0.031 & -0.009 \\
\hline Marital status $\left(\mathrm{X}_{3}\right)$ & $0.013(0.169)$ & 0.168 & -0.298 & 0.353 \\
\hline Family size $\left(\mathrm{X}_{4}\right)$ & $0.239(0.026)$ & $3.157 *$ & 0.030 & 0.131 \\
\hline Number of years lived in the village $\left(\mathrm{X}_{5}\right)$ & $0.271(0.004)$ & $2.971 *$ & 0.004 & 0.019 \\
\hline Education level $\left(\mathrm{X}_{6}\right)$ & $0.060(0.136)$ & 0.784 & -0.159 & 0.368 \\
\hline Occupation $\left(\mathrm{X}_{7}\right)$ & $-0.096(0.011)$ & -1.337 & -0.552 & 0.107 \\
\hline Land size $\left(\mathrm{X}_{8}\right)$ & $0.095(0.019)$ & 1.127 & -0.018 & 0.065 \\
\hline Land tenure $\left(\mathrm{X}_{9}\right)$ & $0.106(0.177)$ & 1.481 & -0.086 & 0.601 \\
\hline Access to forest resource $\left(\mathrm{X}_{10}\right)$ & $0.089(0.143)$ & 1.231 & -0.105 & 0.453 \\
\hline Number of climate stresses $\left(\mathrm{X}_{11}\right)$ & $-0.038(0.014)$ & -0.558 & -0.141 & 0.079 \\
\hline Trend of rainfall (increasing/decreasing) $\left(\mathrm{X}_{12}\right)$ & $0.152(0.293)$ & $2.157^{*}$ & 0.053 . & 1.215 \\
\hline Shift in rain seasons $\left(\mathrm{X}_{13}\right)$ & $0.125(0.318)$ & 1.835 & -0.043 & 1.181 \\
\hline Trend of temperature (increasing/decreasing) $\left(\mathrm{X}_{14}\right)$ & $0.299(0.117)$ & $3.948 *$ & 0.230 & 0.692 \\
\hline Shift in monthly temperature trends (high/low) $\left(\mathrm{X}_{15}\right)$ & $0.096(0.174)$ & 1.353 & -0.108 & 0.577 \\
\hline
\end{tabular}

$\mathrm{R}^{2}=0.43 ;$ Adj $\mathrm{R}^{2}=0.35 ; \mathrm{F}-$ Value $=4.878 ;$ *Significant at 0.05 level; Figures in parenthesis are standard errors (SE)

\section{References}

Augustino, S., Makonda, F.B.S., Shemdoe, R.S., Ishengoma, R.C., Gillah, P.R. and Migunga, G.A. (2012), Climate change impacts and adaptation: Preliminary observations from forest adjacent communities in Kilombero District, Tanzania. In: Procedings of the First Climate Change Impacts, Adaptation and Mitigation Programme Scientific Conference, Blue Pearl Hotel, Dar es Salaam, Tanzania $2^{\text {nd }}$ and $3^{\text {rd }}$ January, 2012. pp. 118-130. Abdulla, S.M.K. (2000), Malaria control strategies in the Kilombero Valley, Tanzania. Thesis for Award of PhD Degree at University of Basel, Switzerland. 198pp.

Allarangaye, M.D., Traore, O. Traore, E.V.S., Millogo, R.J. and. Konate, G. (2006), Evidence of non-transmission of rice yellow mottle virus through seeds of wild host species. Journal of Plant Pathology, 88(3), 309-315.

Ayanwuyi, E.K., Odunlade, F.A. and Oyetoro, J.O. (2010), Farmers' perception of impact of climate change on food crops in Ogbomosho Agricultural Cone of Oyo State, Nigeria. Global Journal of Human Social Science 10(7), 33-39.

Bakengesa, S., Munishi, P. and Navrud, S. (2011), Potential climate change impacts on direct economic values from wildlife in the
Kilombero Ramsar Site, Tanzania. In: Experiences of Climate Change Adaptation in Africa, Climate Change Management. (Edited by W. Leal Filho), Springer-Verlag Berlin Heidelberg. pp. 33-53.

Berman, R., Quinn, C. and Paavola, J. (2012), The role of institutions in the transformation of coping capacity to sustainable adaptive capacity. Environmental Development, 2, 86 - 100.

Chamwali, A. (2000), Survival and accumulation strategies at the rural-urban interface: a study of Ifakara Town, Tanzania. REPOA. 63pp.

Devisscher, T. (2010), Ecosystem-based Adaptation in Tanzania: The Role of Ecosystem Services for Human Well-Being and Climate Adaptation. Ecosystems Report for the Economics of Climate Change in Tanzania Project. Development Partners Group, UK. 45pp. Ellis, F. (2000). Rural Livelihoods and Diversity in Developing Countries. Oxford University Press Incl., New York. 273pp.

Eriksen, S. and Lind, J. (2009), Adaptation as a political process: Adjusting to drought and conflict in Kenya's drylands. Environmental Management, 43(5), 817-835.

Eriksen, S.H., Brown, K. and Kelly, P.M. (2005), The dynamics of vulnerability: locating coping 
strategies in Kenya and Tanzania. The Geographical Journal, 171(4), 287 - 305.

Hetzel, M.A.W., Alba, S., Fankhauser, M., Mayumana, I., Lengeler, C., Obrist, B., Nathan, R., Makemba, A.M., Mshana, C., Alexander Schulze, A. and Mshinda, H. (2008), Malaria risk and access to prevention and treatment in the paddies of the Kilombero Valley, Tanzania. Malaria Journal, 7,7 doi:10.1186/1475-2875-7-7. IPCC (2007a), Assessment of adaptation practices, options, constraints and capacity. Climate Change 2007: Impacts, Adaptation and Vulnerability. Contribution of Working Group II to the Fourth Assessment Report of the Intergovernmental Panel on Climate Change, Parry, M.L., Canziani, O.F., Palutikof, J.P., van der Linden, P.J. and Hanson, C.E., Eds., Cambridge University Press, Cambridge, UK. pp. 717-743.

IPCC (2007b), Food, fibre and forest products. Climate Change 2007: Impacts, Adaptation and Vulnerability. Contribution of Working Group II to the Fourth Assessment Report of the Intergovernmental Panel on Climate Change, M.L. Parry, O.F. Canziani, J.P. Palutikof, P.J. van der Linden and C.E. Hanson, Eds., Cambridge University Press, Cambridge, UK. pp. 273 - 313.

Kamanga, P., Vedeld, P. and Sjaastad, E. (2009), Forest incomes and rural livelihoods in Chiradzulu District, Malawi. Ecological Economics, 68, 613-624.

Mbwambo, J.S., Ndelolia, D., Madalla, N., Mnembuka, B., Lamntane, H.A., Mwandya, A.W., and Zahabu, E. (2012), Climate change impacts and adaptation among coastal and mangrove dependent communities: A case of Bagamoyo District. In: Procedings of the First Climate Change Impacts, Adaptation and Mitigation Programme Scientific Conference, Blue Pearl Hotel, Dar es Salaam, Tanzania $2^{\text {nd }}$ and $3^{\text {rd }}$ January, 2012. Climate Change Impacts, Adaptation and Mitigaation in Tanzania (CCIAM), Morogoro. pp. 131 - 141.

Metzger, M.J., Rounsevell, M.D.A., AcostaMichlik, L., Leemans, R. and Schroter, D. (2006), The vulnerability of ecosystem services to land use change. Agriculture, Ecosystems and Environment, 114, 69-85.

Naess, L.O., Bang, G., Eriksen, S. and Vevatne, J. (2005), Institutional adaptation to climate change: Flood responses at the municipal level in Norway. Global Environmental Change, 15, 125-138.

Nkem, J., Kalame, F.B., Idinoba, M., Somorin, O.A., Ndoye, O., Awono, A. (2010), Shaping forest safety nets with markets: Adaptation to climate change under changing roles of tropical forests in Congo Basin. Environmental Science and Policy, 13, 498-508.

Paavola, J. (2008), Livelihoods, vulnerability and adaptation to climate change in Morogoro, Tanzania. Environmental Science and Policy, 11: $642-654$.

Shemsanga, C., Omambia, A.N. and Gu, Y. (2010), The cost of climate change in Tanzania: Impacts and adaptations. Journal of American Science, 6(3), 182-196.

URT (2007), National Adaptation Programme of Action (NAPA). Vice President's Office, Division of Environment, Dar es Salaam. 61pp. 